\title{
QUALITY OF ARABIC COFFEE UNDER DIFFERENT PROCESSING SYSTEMS, DRYING METHODS AND ALTITUDES
}

\author{
QUALIDADE DO CAFÉ ARÁBICA SOB DIFERENTES SISTEMAS DE \\ PROCESSAMENTO, MÉTODOS DE SECAGEM E ALTITUDES
}

\section{Kênia Barbosa do CARMO' ${ }^{1}$; Jéssica Conceição Barbosa do CARMO² Marcelo Rodrigo KRAUSE ${ }^{3}$; Aldemar Polonini MORELI ${ }^{4}$, Paola Alfonsa Vieira LO MONACO}

1. Engenheira Agrônoma, Instituto Federal do Espírito Santo- Campus Santa Teresa, IFES, Santa Teresa, ES, Brasil. keniabcarmo@gmail.com; 2. Engenheira Agrônoma, Universidade Federal de Viçosa - Campus Viçosa, Viçosa, MG, Brasil; 3. Doutorando em Fitotecnia, Universidade Federal de Viçosa - Campus Viçosa, Viçosa, MG, Brasil; 4. DSc. Produção Vegetal, Universidade Federal do Espirito Santo - Campus Alegre- ES e 5. D.S em Engenharia Agrícola, Universidade Federal de Viçosa, Professora Titular do Instituto Federal do Espírito Santo - campus Santa Teresa.

\begin{abstract}
The quality of coffee is one of the most important requirements in the commercialization of the product, and the post-harvest stage is decisive in the production of excellent coffees. The region of Mutum, MG, Brazil, is predominantly coffee-growing, with high potential for the production of specialty coffees. Due to the social and economic importance of coffee production in the Matas de Minas region, research has been demanded with the aim of providing technological information that provides improvements in quality and consequent price aggregation of the coffee bag. Among the several factors that may affect coffee quality are the processing system, the drying method and the altitude. Thus, the objective of this work was to evaluate the quality of Arabica coffee at different altitudes, submitted to different processing systems and drying methods. The work was conducted at the Cabeceira do Imbiruçu, in a randomized complete block design,with treatments arranged in a scheme comprising sub-subdivided plots $(2 \times 2 \times 2)$, with four replications. In the plots, the two altitudes $(850$ and $1050 \mathrm{~m}$ ), in the subplotsthe two processingsystems (dry (natural) and wet (peeled cherry)) and in the sub-subplotstwo drying methods (cement and suspended yard, both covered). Sensory and electrical conductivity analyzes were performed. The fruits of coffee trees located at altitudes of $1050 \mathrm{~m}$ have sensory attributes superior to those of altitudes of $850 \mathrm{~m}$. The best results of the coffee flavor and aroma sensory attributes were obtained in the wet processing system when compared to a dry (natural) processing system. The electrical conductivity of the coffee beans obtained in the wet processing system was lower than that obtained in the dry processing system (natural), which gives a better beverage quality. Drying methods in suspended yard and cement yard, both with plastic cover and if technically conducted, do not influence the sensory characteristics of the Arabica coffee.
\end{abstract}

KEYWORDS: Post-harvest. Specialty coffees. Sensory analysis.

\section{INTRODUCTION}

Coffee production in the 2018 harvest was 61.7 million benefited bags, a $37 \%$ increase over the previous year. This is the largest harvest registered in the historical series of the grain, surpassing by about 10 million bags the best performance recorded in 2016 (CONAB, 2018).

With the increase in Brazilian coffee production year after year, the search for new consumer markets is inevitable, which implies an increasing tendency to produce high quality specialty coffees. Producing quality coffee provides the coffee grower with added value to their product and the possibility of competing more evenly with the world market.
The production of high quality coffees depends mainly on effective planning of each stage of the coffee production chain. Among them, postharvest stands out as one of the most important and determinant, including the stages of coffee bean processing, drying, and storage. In addition, other factors may also interfere, such as soil characteristics, cultivar, geographic location, climate, altitude, as well as "savoir-faire" (knowhow) (BORÉM, 2008; THOMAZINI et al., 2011).

In this context, Gair (2012) studying the effect of altitude, between 500 and 998 meters in the beverage quality of coffee in Paraná, concluded that different altitudes did not influence the sweetness of the coffees. At altitudes above 900 meters, they found that the coffees presented superior flavor quality. In regions with higher altitudes, believed to 
be cooler, coffees get higher grades for taste, aroma, sweetness and body, compared to lower altitude regions, where temperatures are warmer, due to slower maturation and higher accumulation of total sugars in grains at lower temperatures (ANDROCIOLI et al., 2003).

In the same way, coffee processing interferes significantly in its quality, however in the consulted literature no works were found correlating the quality with the form of processing. Postharvest, coffee can be processed in two ways, dry and wet. In dry processing, the fruit is dried in its integral form (with husk), giving rise to the coffees denominated in coconut or natural. Wet processing consists of the removal of the husk, pulp and/or mucilage of the mature fruit, which are substrates favorable to the development of microorganisms that can cause the occurrence of fermentation harmful to the final quality of the product (MALTA, 2011).

Drying is another fundamental post-harvest management of coffee beverage quality. Among the different forms of drying, basically, the three most frequently used by producers today are natural drying, using solar radiation in yards; artificial drying, carried out in rotary dryers by direct or indirect fire and drying in greenhouse systems (covered yard) (REINATO et al., 2012).

Considering the importance of post-harvest management in the quality of the Arabica coffee, this study aimed to evaluate the quality of Arabica coffee at different altitudes, submitted to different processing systems and drying methods.

\section{MATERIAL AND METHODS}

The experiment was carried out in the district of Imbiruçu (LAT-20 $0^{\circ} 10^{\prime} \mathrm{S}, \mathrm{LON}-41^{\circ} 24^{\prime} \mathrm{O}$ ), in the municipality of Mutum, Minas Gerais.

Fruits of Arabica coffee (Coffea arabica L.) cultivar Catuaí 44 Vermelho were used. The fruits were harvested using cloth by means of manual melting at two altitudes, 850 and $1050 \mathrm{~m}$, and then transported in raffia bags to the processing unit. The coffees destined to the dry treatments consisted of coffee beans at the cherry maturation point and went straight to the cement and suspended yard. The peeled cherry coffee went through the humid process, during which stage all the fruits were buoyant and green, keeping only the fruits in mature stage, the cherry coffee peeled. From this stage, the peeled cherry treatments were applied to the drying system in a suspended yard and cement yard, where each experimental plot consisted of 10 liters of coffee. All treatments were randomly arranged in the yards with four replications.

The experiment was carried out in a randomized complete block design,with treatments arranged in a scheme comprisingsub-subdivided plots $(2 \times 2 \times 2)$, with four replications.In the plots, the two altitude $(850$ and $1050 \mathrm{~m})$, in the subplotsthe two processingsystems (dry (natural) and wet (peeled cherry)) and in the sub-subplotstwo drying methods (cement and suspended yard, both covered), totaling eight treatments (Table 1).

Table 1. Treatments evaluated in the experiment considering the combination ofaltitude, processing and drying methods.

\begin{tabular}{llll}
\hline Treatments & Altitude & Process & Drying methods \\
\hline 1 & 850 & Natural & Suspended yard \\
2 & 850 & Natural & Cement yard \\
3 & 1050 & Natural & Suspended yard \\
4 & 1050 & Natural & Cement yard \\
5 & 850 & Peeled cherry & Suspended yard \\
6 & 850 & Peeled cherry & Cement yard \\
7 & 1050 & Peeled cherry & Suspended yard \\
8 & 1050 & Peeled cherry & Cement yard \\
\hline
\end{tabular}

After the separation process, the coffee was dried to $11.5 \%$ moisture (b.u.), in a suspended yard and in a cement yard, both covered, following the hygiene recommendations, layer thickness and tillage, suggested by Borém et al. al. (2008).

During the drying process, rainfall, relative humidity of the external environment and internal environments of the drying units were measured, the maximum and minimum temperatures of the external environment and average temperature of the external environment of the drying units, at 9 am, $12 \mathrm{pm}$ and $3 \mathrm{pm}$. In this procedure, the measuring apparatus was positioned on the mass of grains. The electrical conductivity and sensory analyzes of the grains were also carried out to determine the quality.

For the determination of electrical conductivity, a test was conducted, using 50 grains 
of each treatment, which were weighed and placed in plastic cups containing $75 \mathrm{~mL}$ of deionized water. They were then taken to the BOD chamber at $25^{\circ} \mathrm{C}$ for 24 hours. The reading was made in a conductivity meter, by immersing the electrodes in the imbibition water. The results were expressed in $\mu \mathrm{S} \mathrm{cm}^{-1} \mathrm{~g}^{-1}$. (PRETE, 1992).

The sensory analysis of the coffee beverage was performed by four trained tasters and qualified as Certified Cupping Judges (SCAA), belonging to the IFES server board - Campus Venda Nova do Imigrante - ES. Samples were prepared and coded and sent to the laboratory. The roasting and sensory analysis of the samples were performed according to the methodology proposed by the Specialty Coffee Association of America - SCAA (LINGLE, 2011). At each evaluation, five cups of coffee were sampled from each sample and scores were scored from 0 to 10 points for each of the following attributes: fragrance/aroma, uniformity, absence of defects, sweetness, taste, acidity, body, balance and overall impression. The final grade represented the sum of the attributes.

Data were submitted to variance analysis, considering the main effects of the factors and their interaction. As for each factor there are only two levels, the variance analysis was conclusive for all variables. The procedures were performed considering an $\alpha$ of up to 5\% probability, using SAS University software (CODY, 2015).

\section{RESULTS AND DISCUSSION}

The period that was necessary to perform the drying of the natural coffee beans was 18 days and the cherries peeled 9 days, there was no precipitation, a factor that contributed positively to the process. The average time for complete drying of the coffee beans in the yard is variable and depends on the characteristics of the product, the type of yard, as well as the climatic conditions of each region, varying from 15 to 20 days for the natural coffee, being able to reach up to 30 days for unfavorable conditions such as in the Zona da Mata of Minas Gerais, and from 8 to 12 days for parchment coffees (GIRANDA, 1998).

According to Figure 1, the average maximum temperature was found to be above $32^{\circ} \mathrm{C}$ and the average minimum temperature was above $15.19{ }^{\circ} \mathrm{C}$. It is further verified that the maximum temperature values were $28.38 ; 30.60$ and $32.84{ }^{\circ} \mathrm{C}$ at the times of 9,12 and 15 (o'clock), respectively. The minimum temperature values were $15.19 ; 20.88$ and $25.82^{\circ} \mathrm{C}$ at $9 \mathrm{am}, 12 \mathrm{pm}$ and $3 \mathrm{pm}$, respectively.

According to the Coffee University Notebook (2015), in mechanical drying, of the top ten placed in the contest, $85 \%$ of the finalists dry the coffee mass at a temperature between $30^{\circ}$ and $35^{\circ} \mathrm{C}$, instead of $40^{\circ} \mathrm{C}$.

In order to obtain high quality beverages in mechanical drying, the temperature must not exceed $39^{\circ} \mathrm{C}$ for the coffee with husk. (EMBRAPA, 2006).

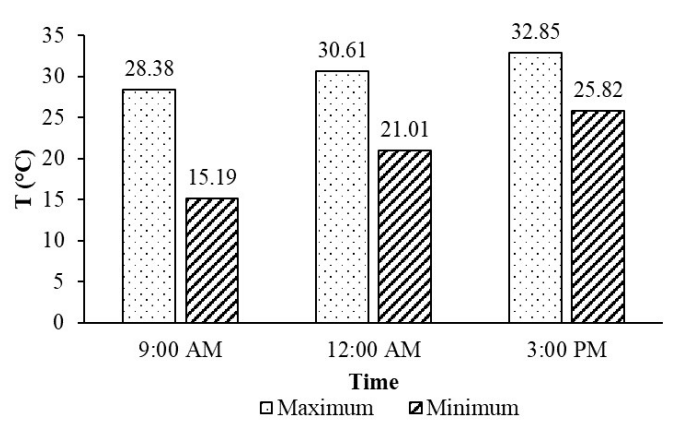

Figure 1. Average maximum and minimum ambient temperatures.

Imbiruçu, Mutum.

According to Figure 2, it can be seen that the mean external $\mathrm{RH} \%$ was $57.74 ; 46.03$ and $48.06 \%$, at $9 \mathrm{am}, 12 \mathrm{pm}$ and $3 \mathrm{pm}$, respectively. The highest $\mathrm{RH} \%$ in the cement yard was $55.26 \%$ at 9 am and the lowest value at $45.74 \%$ at $12 \mathrm{pm}$. In the suspended yard the highest value was $50.06 \%$ at 9 am and the lowest value was $40.84 \%$ at $12.00 \mathrm{pm}$.

$\mathrm{RH} \%$ mean during the day in the external environment was $50.61 \%$, in the suspended yard it was $45.12 \%$ and in the covered cement yard it was $49.90 \%$. This decrease in RH can be explained by the coverage with the transparent plastic canvas in both drying environments. In addition, the drying of the fruits in suspended bed, avoids contact with the soil, allowing greater aeration, evidencing, thus, one of the advantages of the method.

It can be seen that the $\mathrm{RH} \%$ of the external environment at 9 am is higher than the internal $\mathrm{RH} \%$ in the drying environments. This justifies the use of covered yards in the region, since it serves as a "barrier" of high humidity mainly in the nocturnal period. 
The use of the covered yard is an alternative that allows the drying of large quantities of coffee, in regions with difficulty to find flat land suitable for the construction of traditional yards. The use of the greenhouse is also an alternative in places with high relative humidity during the nights and in the early hours of the morning, with the risk of dew formation and re-wetting of dry coffee (DONZELES el al., 2011).

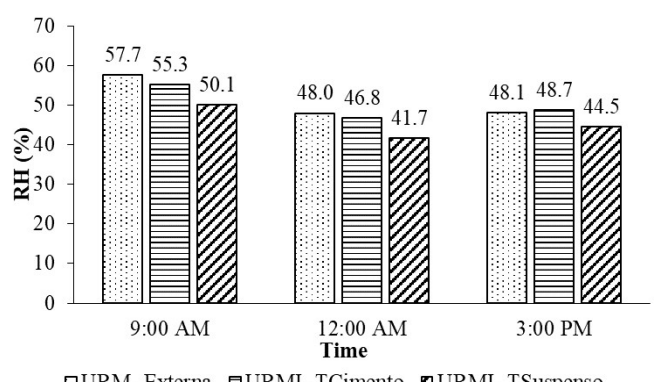

Figure 2. Mean relative humidity (MRH-external), internal relative humidity of the cement yard (MIRH-Y Cement) and internal relative humidity of the suspended yard (MIRH-Y Suspended).

According to Figure 3, the mean ambient temperature values obtained were found to be 24.73 ; 30.87 and $25.91^{\circ} \mathrm{C}$, at $9 \mathrm{am}, 12 \mathrm{pm}$ and $13 \mathrm{pm}$, respectively. The internal temperature in the cement yard reached the highest value at $12 \mathrm{pm}$, with $28.27^{\circ} \mathrm{C}$; the lowest value was recorded at $9 \mathrm{am}$, with $25.77^{\circ} \mathrm{C}$; and at $3 \mathrm{pm}$ there was a slight decrease, with an average value of $27.41{ }^{\circ} \mathrm{C}$ recorded. In the suspended yard, the highest value occurred at $12 \mathrm{pm}$ with $31.28^{\circ} \mathrm{C}$; the lowest at 9 am with $27.43^{\circ} \mathrm{C}$ and at $3 \mathrm{pm}$ reached $28.64^{\circ} \mathrm{C}$. The average temperature during the day was $27.15^{\circ} \mathrm{C}$ in the cement yard and $29.11^{\circ} \mathrm{C}$ in the suspended yard.

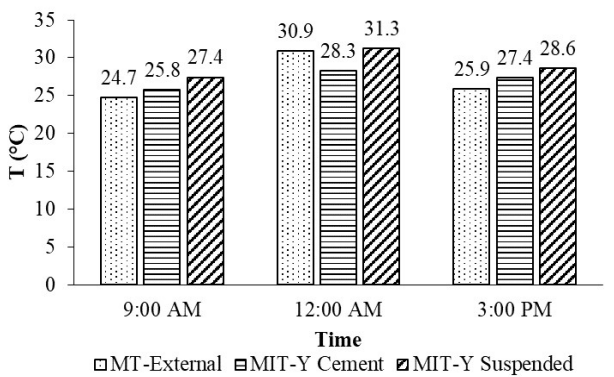

Figure 3. Mean ambient temperature (MT-External), cement yard internal temperature (MIT-Y Cement) and suspended yard (MIT-Y Suspended).

Comparing the average temperatures obtained in the internal environments (cement and suspended yards) with those obtained in the external environment, it can be verified that the average temperatures were higher than the external environment, when measured at 9 am and $3 \mathrm{pm}$. This fact occurred due to the presence of a transparent plastic canvas cover, which maintains the heat in these environments, when managed according to the technical recommendations of Silva and Herbert (1999). When comparing the average temperatures of the internal environments, it is verified that the average temperatures in the suspended yard were higher, in the three schedules evaluated, when compared to the cement yard. This fact can be explained by the volume of the area covered in the cement yard being larger and higher than that of the suspended yard, and that the warm air being lighter must rise and dissipate in the larger area and the area and height are smaller in the suspended yard. It is important to note that a high temperature and medium relative humidity did not occur during the drying period of the grains, providing good natural conditions to the drying process, which contributed to the maintenance of grain quality characteristics.

Coffee processed via dry (natural) in both drying methods, took longer to complete than peeled cherry coffees. According to Borém et al. (2008), the permanence of the husk gives the fruit of the coffee tree a structure with greater resistance to injuries and the need for a longer drying time in order to reach the ideal moisture for grain storage when compared to other types of processing. It should be noted that the differences between natural (dry) and peeled (wet) coffee are related to the 
presence of epicarp and mesocarp in natural coffees. This fact makes it more difficult for the water to escape from the interior of the fruit, causing the temperature inside the beans to increase, which can cause damage to the integrity of the cell membranes more intensely in the natural coffee than in the demucilated one, even subjecting the beans to the same drying method (SAATH et al., 2012).
The results of the variance analysis performed for each sensory attribute of the grains, as well as the mean scores, can be observed in Tables 2 and 3. The variables uniformity, absence of defects and sweetness were not subjected to variance analysis, since no presented variation between the data of the repetitions and the treatments, all of which received a score of 10.

Table 2. Effect of altitude on the sensory attributes of Arabica coffee. Mutum-MG, Brazil. 2016.

\begin{tabular}{lllllllll}
\hline Altitude & Aroma & Flavor & Acidity & Body & Finishing & Balance & Final & Total \\
\hline $850 \mathrm{~m}$ & $7.39 \mathrm{~b}$ & $7.22 \mathrm{~b}$ & $7.17 \mathrm{~b}$ & $7.05 \mathrm{~b}$ & $7.09 \mathrm{~b}$ & $7.00 \mathrm{~b}$ & $7.16 \mathrm{~b}$ & $80.08 \mathrm{~b}$ \\
$1050 \mathrm{~m}$ & $7.78 \mathrm{a}$ & $7.56 \mathrm{a}$ & $7.48 \mathrm{a}$ & $7.39 \mathrm{a}$ & $7.30 \mathrm{a}$ & $7.20^{\mathrm{a}}$ & $7.31 \mathrm{a}$ & $82.00 \mathrm{a}$ \\
\hline $\mathrm{P}$ value & $<0.0000$ & 0.0002 & $<0.0000$ & $<0.0000$ & 0.0016 & $<0.0000$ & 0.0137 & $<0.0000$ \\
\hline
\end{tabular}

Means followed by the same letters in the column do not differ from each other with an $\alpha$ of up to $5 \%$ probability by the $\mathrm{F}$ test.

Table 3. Effect of processing methods on the electrical conductivity, aroma and taste of arabic coffee.

\begin{tabular}{llll}
\hline Process & Aroma & Flavor & $\mathbf{E C}\left(\boldsymbol{\mu} \mathbf{S} \mathbf{~ c m}^{-1} \mathbf{g}^{-1}\right)$ \\
\hline Dry & $7.47 \mathrm{~b}$ & $7.22 \mathrm{~b}$ & $221.50 \mathrm{a}$ \\
Wet & $7.70 \mathrm{a}$ & $7.56 \mathrm{a}$ & $180.95 \mathrm{~b}$ \\
\hline P value & 0.0051 & 0.0002 & $<0.0000$ \\
\hline Means followed by the same letters in the column &
\end{tabular}

The results indicated that for the acidity, body, aroma, finalization, balance, overall result and final result variables, there was difference for the isolated effect of altitude $(\mathrm{P}<0.05)$. For the aroma and flavor variables, there was a difference between the altitude stratum and the processing system, whereas for EC there were differences only for the processing system (Tables 2 and 3 ).

When analyzing Table 2 , it is verified that the best results in all the evaluated attributes are observed at the altitude of $1050 \mathrm{~m}$. This is justified because the fruit of the coffee tree undergoes a slower maturation at this altitude due to the climatic conditions (lower temperatures). However, it is observed that at altitude $(850$ and $1050 \mathrm{~m})$ they present sensory characteristics with highly satisfactory results. When submitted to classification in the quality scale, both presented excellent grades, since coffees with a score above 80.0 are considered special.

Solares et al. (2000), who studied the different cultivars produced in Guatemala, concluded that altitude had an influence on the quality of the coffee beverage, regardless of the cultivar, because the sensory properties (body, aroma and softness) increased as the altitude increased. This influence was lower only for the acidity attribute. Ribeiro (2013), when analyzing the effect of altitude and other factors on the chemical contents of the raw grain and the quality of the beverage, observed that the cultivars Bourbon
Amarelo and Acaiá from crops above 1,200 meters of altitude also presented better sensory notes

In the advanced stages, grain filling is more critical in lower altitude conditions, since the plant needs to complete these processes in a shorter time (LAVIOLA et al., 2007). Cortez (2001) observed that anticipation in maturation is one of the factors responsible for the loss of coffee quality. That justifies the lowest scores in the altitude of $850 \mathrm{~m}$.

It can be observed in Table 3 that there was a statistical difference between the aroma, flavor and EC variables, when compared between the two processing systems, and the best results were obtained in wet processing.

There are three important characteristics that indicate the quality of the beverage as a function of the roast degree, and in light colored roast the predominant characteristic is the acidity, but as the roast increases, that is, it becomes darker, the carbonization of some components occurs, therefore, accentuating the burnt flavor. The aroma and body are more accentuated (MELO, 2004), which justifies why the aroma and flavor attributes have been statistically different in Table 2 .

The lowest values of the electrical conductivity in the coffee beans were in the wet process, being the same with the best sensory quality (Figure 4). Borém et al. (2006) observed that lower values of electrical conductivity are related to a better quality beverage.

The wet coffee processing provided the lowest EC values and notes above 80 points, 
considered soft drink coffees (Figure 4), with EC of $221,50 \mu \mathrm{S} \mathrm{cm}^{-1} \mathrm{~g}^{-1}$. The dry EC treatments were $180 \mu \mathrm{S} \mathrm{cm}^{-1} \mathrm{~g}^{-1}$ The higher electrical conductivity values in the natural coffee can occur because the differences between the natural and demucilated coffees are related to the presence of the epicarp and the mesocarp in the natural coffees, which causes greater difficulty for the exit of water from the interior of the fruit, due to physical barriers, causing the temperature inside the grains to increase, which can cause damage to the integrity of the cell membranes more intensely in the natural coffee than in the demucilated one, even when subjecting the grains to the same drying method (SAATH et al., 2012).

In studies carried out in Lavras-MG, aiming to evaluate the sensory quality of coffee beans, processed and dried in different forms and temperatures, the authors concluded that the drying in yards provided the best sensory quality of the coffee beans, when compared to the drying with hot air and that the pulped coffee had better sensory quality than the natural coffee, regardless of the drying method (ALVES et al., 2011).

Figure 4 presents the average cup test scores for the attribute "Final Score", performed for arabic coffee beans beverage quality, according to the processing systems (dry and wet) and drying methods (suspended and cement), in two altitudes (850 and $1050 \mathrm{~m})$.

It was verified that all the treatments provided results with specialty coffee classification, except those that were submitted to the "natural" processing system, in both methods of drying, with altitude of $850 \mathrm{~m}$. Even so, they presented values very close to those that are classified as specialty, these being classified as fine commercial coffees. According to the SCAA (2008) scale of sensory evaluation of specialty coffees, the quality of the coffee, based on the Final Score scores of the sensory evaluation, with a score above 80.0 are considered specialty coffees.

The treatments with higher scores were those of altitude of 1050 meters, as demonstrated by the attributes in Table 1 and Figure 4. Comparing the processing systems, the peeled cherry treatments obtained higher scores than the natural ones. According to Lima et al., (2008) the coffees produced by the dry method are of comparatively inferior quality to the coffees produced by the humid method.

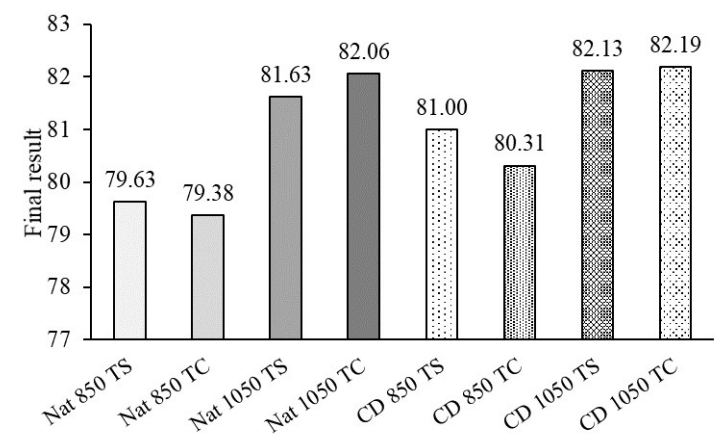

Figure 4. Mean scores of the sensory analysis for the attribute "Final result", carried out on Arabica coffee beans, depending on the processing systems and the drying methods.

Mutum - MG. 2016.

Nat: natural, CD: peeled cherry; TS: Suspended yard, TC: Cement yard; $850 \mathrm{~m}$ and 1050m: altitudes.

Table 4shows the effect of the drying and processing method on the "finalization" variable of Arabica coffee. It is verified that for this variable there was interaction between the factors "processing system" and "drying method" $(\mathrm{P}<0.05)$.

For this variable, it was observed that, when drying in suspended yard, processing via humid presented results superior to the dry method $(\mathrm{P}<0.05)$. When drying in a cement yard, there was no difference between the processing method $(\mathrm{P}<0.05)$.

The suspended screen yard is currently highly recommended because it consists of a suspended structure that prevents the coffee from touching the ground, receives greater aeration both above and below, prevents the attack of microorganisms and ensures a product with drying uniform and of better quality. This type of yard provides greater reduction of labor, decrease of the drying time, besides having simple, fast and cheap construction. The use of cover with translucent plastic is advisable in regions where the harvest coincides with the rainy season (SILVA; HERBERT, 1999).

The presence of mucilage promotes greater vulnerability of natural coffees to the growth of 
microorganisms. For this reason, mucilage removal techniques are adopted to reduce the chances of loss of quality, such as fermentation and mechanical demisting. In addition to decreasing the drying time and space in the yards/patios, the removal of the husk can provide greater softness to the coffee beverage by the selectivity of the lots as to the different stages of maturation, aiming at the formation of micro-lots. In regions where relative humidity is high during the harvesting period, the processing, the drying of the fruits, peeling is an interesting option avoiding undesirable fermentation that can reduce the quality of the coffees (MALTA; SANTOS; SILVA, 2002).

Table4. Effect of the drying and processing method on the finalization of Arabica coffee.

\begin{tabular}{llll}
\hline & \multicolumn{2}{l}{ Drying method } & \\
\cline { 2 - 3 } Process & Suspended yard & Cement yard & \\
\hline & Finalization & & $\mathbf{0 . 3 2 2 1}$ \\
\cline { 2 - 4 } Dry & $7.09 \mathrm{Ab}$ & $7.19 \mathrm{Aa}$ & $\mathbf{0 . 1 9 0 1}$ \\
\hline Pet & $7.31 \mathrm{Aa}$ & $7.19 \mathrm{Aa}$ & \\
\hline value & $\mathbf{0 . 0 2 3 8}$ & $\mathbf{1 . 0 0 0 0}$ & \\
\hline
\end{tabular}

Means followed by the same uppercase letters in the row and lower case letters in the column do not differ from each other with an $\alpha$ of up to $5 \%$ probability by the $\mathrm{F}$ test.

According to the statistical analysis, there was no significant difference in the attribute Final Result $(\mathrm{P}<0.05)$. Even in this circumstance, the flavors are different among the coffees (Table 5), which is an important aspect in the commercialization and the search for quality standards (SCAA, 2008).

According to Table 5, it can be observed that the $\mathrm{T} 1, \mathrm{~T} 2$ and $\mathrm{T} 6$ treatments obtained characteristics of immature fruits, these being treatments with three smaller global scores with 79.6; 79.3 and 80.3 points (Figure 4), respectively. Characteristics like fruits and citrus are desired by the market, being related to superior quality. It is observed that these characteristics were found at $1050 \mathrm{~m}$ altitude, which shows that higher altitudes produce coffee with different aromas.

Table5. Coffee flavors in relation to each treatment.

\begin{tabular}{lllll}
\hline Treatments & Process & Altitude & $\begin{array}{l}\text { Drying } \\
\text { method }\end{array}$ & Flavors \\
\hline 1 & Natural & 850 & $\begin{array}{l}\text { Suspended } \\
\text { Yard } \\
\text { Cement Yard }\end{array}$ & $\begin{array}{l}\text { Caramel, Immature, Almonds/Chocolate. } \\
\text { Chocolate/Caramel e Immature. } \\
\text { Suspended } \\
\text { Yattery/Chocolate, Caramel, Almonds, } \\
\text { Almonds/caramel and Chocolate. }\end{array}$ \\
$\begin{array}{llll}\text { Caramel, Chocolate, Full Acidity / Red } \\
\text { Fruits,Chocolate/Citric Caramel } \\
\text { and Chocolate/Caramel. }\end{array}$ \\
5
\end{tabular}

According to Malta (2011), the differentiation of specialty coffees takes into account attributes of floral, citrus, aroma, among others, and special flavor characteristics such as chocolate, roasted peanuts, caramel and others. For
Brazil Especialty Coffee Associantion - BSCA (2015), specialty coffees are those that do not present primary defects (sticks, stones, green coffees, etc.) and that present something that differentiates them from others, such as floral, 
Quality of arabic coffee...

citrus, among others, adding value to the product. In Matas de Minas you can find cafes with remarkable characteristics such as: sweet taste, with a diversity of citrus, caramel and chocolate flavors; intense aroma with floral and citric notes; body ranging from full bodied to very full bodied; delicate and balanced acidity and pleasant and prolonged finish (MATAS DE MINAS REGION, 2015).

\section{CONCLUSIONS}

The fruits of coffee trees located in altitudes of $1050 \mathrm{~m}$ have sensory attributes superior to those of altitudes of $850 \mathrm{~m}$;

The results of the flavor and aroma sensory attributes of coffee obtained in the wet processing method or system are higher than those obtained in the dry (natural) processing system;
CARMO, K. B. et al.

The electrical conductivity of the coffee beans obtained in the wet processing system is lower than that obtained in the dry (natural) processing system, which gives better beverage quality;

Drying methods in suspended yard and cement yard, both with plastic cover and if technically conducted, do not influence the sensory characteristics of the Arabica coffee.

The interaction of the drying method in suspended yard and the wet process provides a better finish.

\section{ACKNOWLEDGEMENTS}

The authors thank the PRODIF for financial assistance

RESUMO: A qualidade do café é um dos requisitos mais importantes na comercialização do produto, sendo a etapa de pós-colheita determinante na produção de cafés de excelência. A região de $\mathrm{Mutum}$, MG, Brasil, é predominantemente cafeeira, com elevado potencial de produção de cafés especiais. Em razão da importância social e econômica da cafeicultura para a região das Matas de Minas, pesquisas têm sido demandadas com o intuito de fornecer informações tecnológicas que proporcionem melhorias na qualidade e consequente na agregação do preço da saca de café. Dentre os diversos fatores que podem afetar a qualidade do café destacam-se o sistema de processamento, o método de secagem e a altitude. Assim, objetivou-se com a realização deste trabalho, avaliar a qualidade do café arábica em diferentes altitudes, submetido a diferentes sistemas de processamento e métodos de secagem. O trabalho foi conduzido na propriedade cabeceira do Imbiruçu, em um delineamento experimental de blocos casualizados, com os tratamentos dispostos em um esquema de parcelas sub-subdivididas $(2 \times 2 \times 2)$, com quatro repetições, sendo nas parcelas, as duas altitudes $(850$ e $1050 \mathrm{~m})$, nas subparcelas, os dois sistemas de processamento (seco (natural) e úmido (cereja descascada)) e nas subparcelas, dois métodos de secagem (cimento e terreiro suspenso, ambos cobertos). Foram realizadas análises sensoriais e de condutividade elétrica. Os frutos de cafeeiros localizados em altitudes de $1050 \mathrm{~m}$ possuem atributos sensoriais superiores aos de altitudes de $850 \mathrm{~m}$. Os melhores resultados dos atributos sensoriais sabor e aroma do café foram obtidos no sistema de processamento via úmida quando comparado como sistema de processamento via seca (natural). A condutividade elétrica dos grãos de café obtidos no sistema de processamento via úmida foi menor que a obtida no sistema de processamento via seca (natural), $\mathrm{o}$ que confere melhor qualidade de bebida. Os métodos de secagem em terreiro suspenso e em terreiro de cimento, ambos com cobertura plástica e se tecnicamente conduzidos, não influenciam nas características sensoriais do café arábica.

PALAVRAS-CHAVE: Pós-colheita. Cafés especiais. Análise sensorial.

\section{REFERENCES}

ALVES, G. E.; OLIVEIRA, P. D.; ISQUIERDO, E. P.; BORÉM, F. M.; PEREIRA, C. C.; RIBEIRO, D. E. Análise sensorial de grãos de café submetidos a diferentes tipos de processamento e métodos de secagem. In: VII Simpósio de Pesquisa dos Cafés do Brasil; Anais... Araxá - MG. 2011.

ANDROCIOLI, A.; LIMA, F. B.; TRENTO, E. J.; CARNEIRO, F.; CARAMORI, P.H.; SCHOLZ, M. B. dos S. Caracterização da qualidade da bebida dos cafés produzidos em diversas regiões do Paraná. In. Simpósio de Pesquisa dos Cafés do Brasil, 3, 2003, Porto Seguro. Resumos... Brasília: Embrapa Café, p 256-257, 2003. 
BRAZIL ESPECIALTY COFFEE ASSOCIANTION- BSCA. Disponível em: $<$ http://bsca.com.br/cafesespeciais.php>. Acesso em: 30 de jan. 2015.

BORÉM, F. M.; RIBEIRO, D. M.; PEREIRA, R. G. F. A.; ROSA, S. D. V. F.; MORAIS, A. R. Qualidade do café submetido a diferentes temperaturas, fluxos de ar e períodos de pré-secagem. Coffee Science, Lavras, v. 1, n. 1, p. 55-63, abr./jun. 2006.

BORÉM, F. M. Pós colheita do café. Lavras: UFLA, 630 p. 2008.

BORÉM, F. M.; CORADINI, P. C.; OLIVEIRA, J. A. Qualidade do café natural e despolpado após secagem em terreiro e com altas temperaturas. Ciência e Agrotecnologia, Lavras, v. 32, n. 5, p. 1605-1615, set./out. 2008. https://doi.org/10.1590/S1413-70542008000500038

CODY, R. An Introduction to SAS University Edition. SAS Institute, 2015.

CONAB - Companhia Nacional de Abastecimento. Acomp. safra bras. café.Safra 2018. Quarto Levantamento, Brasília, p. 1-84 vol. 5, n.4, Dez. 2018. Disponível em:

file:///C:/Users/K\%C3\%AAnia/Downloads/BoletimZCafeZdezembroZ2018_1.pdf

CORTEZ, J. G. Efeito de espécies e cultivares e do processamento agrícola e industrial nas características da bebida do café. 71p, Tese (Doutorado) - Escola Superior de Agricultura Luiz de Queiroz, Piracicaba, 2001.

DONZELES, S. M. L.; SAMPAIO, C. P.; SOARES, S. F.; RIBEIRO, M. de F. Colheita e processamento do café arábica. In: REIS, P.R.; CUNHA, R.L. da; CARVALHO, G.R. Café Arábica: da pós-colheita ao consumo. Lavras: EPAMIG SM,2 v. 734p.:il. cap.1, p.19-66, 2011.

EMBRAPA. Cultivo do café orgânico. 2006. Disponível em: <https://sistemasdeproducao.cnptia.embrapa. br/FontesHTML/Cafe/CafeOrganico_2ed/index.htm>. Acesso em: 10 maio 2018.

GAIR, R. Efeito da altitude na qualidade da bebida do café. Dissertação (Mestrado em Agronomia). Universidade Estadual de Londrina. 57p, 2012.

GIRANDA, R. N. Aspectos qualitativos de cafés (coffeaarabicaL.) submetidos a diferentes processos de secagem. 1998. 83 p. Dissertação (Mestrado em Ciências dos Alimentos) - Universidade Federal de Lavras, Lavras, 1998.

LAVIOLA, B. G.; MARTINEZ, H. E. P.; SALOMÃO, L. C. C.; CRUZ, C. D.; MENDONÇA, S. M.; ROSADO, L. D. S. Acúmulo de nutrientes em frutos de cafeeiro em duas altitudes de cultivo: micronutrientes. Revista Brasileira de Ciência do Solo, v. 31, n. 6, p. 212-221, 2007. https://doi.org/10.1590/S010006832007000600021

LIMA, M. V. et al. Preparo do café despolpado, cereja descascado e natural na região sudoeste da Bahia. Revista Ceres, Viçosa, MG, v. 55, n. 2, p. 124-130, mar./abr. 2008.

LINGLE, T. R. The coffee cupper's handbook: systematic guide to the sensory evaluation of coffee's flavor. 4th ed. Long Beach: Specialty Coffee Association of America, 66 p.2011.

MALTA, M. R. Critérios utilizados na avaliação da qualidade do café. Informe Agropecuário, v.32, n.261, p.114-126, 2011.

MALTA, M. R. Normas e Padrões Utilizados na Classificação do Café. In: Reis, P. R;Cunha, R. L.; Carvalho, G. R.. Café Arábica da pós-colheita ao consumo. Lavras: U.R. EPAMIG SM., p. 339-413, 2011. 
MALTA, M. R.; SANTOS, M. L. dos; SILVA, F. A. de M. Qualidade de grãos de diferentes cultivares de cafeeiro (CoffeaarabicaL.). Acta ScientiarumAgronomy, Maringá, v. 24, p. 1385-1390, jan./dez.2002. https://doi.org/10.4025/actasciagron.v24i0.2386

MELO, W. L. B. A importância da informação sobre do grau de torra do café e sua influência nas características organolépticas da bebida. 2004. Embrapa. Disponível em: <

https://www.infoteca.cnptia.embrapa.br/infoteca/bitstream/doc/30170/1/CT582004.pdf/>. Acesso em 29 abril. 2020.

PRETE, C. E. C. Condutividade elétrica do exsudato de grãos de café (Coffea arabica L.) e sua relação com a qualidade da bebida. 1992.125p. Tese (Doutorado em Fitotecnia) - Escola Superior de Agricultura Luiz de Queiroz, Piracicaba. 1992.

REGIÃO DAS MATAS DE MINAS. A região. Disponível em: Disponível em: $<$ http://www.matasdeminas.org.br/?noticia $=35 \&$ titulo $=$ Regi $\% C 3 \% A 3 o+$ das + Matas + de + Minas + tem + os $+\mathrm{m}$ elhores + caf\%C3\%A9s+do+Estado\&mes=11\&ano $>$.Acesso em 19 Jul. 2015.

REINATO, C. H. R. et al. Qualidade do café secado em terreiros com diferentes pavimentações e espessuras de camada. Coffee Science, Lavras, v. 7, n. 3, p. 223-237, set./dez. 2012.

RIBEIRO, D. E. Interação genótipo e ambiente na composição química e qualidade sensorial de cafés especiais em diferentes formas de processamento. 2013. 62 p. Dissertação (Mestrado em Processamento de Produtos Agrícolas) - Universidade Federal de Lavras, Lavras, 2013.

SAATH, R. et al. Alterações na composição química e sensorial de café (CoffeaarabicaL.) nos processos póscolheita. Energia na Agricultura, Botucatu, v. 27, n. 2, p. 96-112, 2012.

https://doi.org/10.17224/EnergAgric.2012v27n2p96-112

SCAA CUPPING PROTOCOLS, TSC - SCAA. Rev. em December 2008. DOC V -Portuguese. Disponível em: http://coffeetraveler.net/wp.content/files/901-

scaa_CuppingProtocols_TSC_DOCV_RevDec08_Portuguese.pdf. Acesso em: 10 de novembro de 2017.

SILVA, J. S.; HERBERT, P. A. Colheita, secagem e armazenamento. Viçosa: Aprenda Fácil, p.145,1999.

SOLARES, P. F.; JIMÉNEZ, O. H.; LÉON, E. L.; ANZUETO, F. Influência de la variedade y la altitude enlas características organolépticas y físicas del café. In: SIMPOSIO ATINOAMERICANO DE CAFICULTURA, 19, 2000, San José. Anais... San José: IICA; Promecage, p. 493-499, 2000.

THOMAZINI, A.; TOMAZ, M.; MARTINS, L. D. RODRIGUES, W. N. Abordagem sobre qualidade da bebida no café conilon. EnciclopédiaBiosfera, Goiânia, v. 7, n. 12, p. 1-16, 2011. 